\title{
IMMUNIZATION OF BOVINE CALVES WITH CELL CULTURE, VACCINE AGAINST THEILERIA ANNULATA ${ }^{1}$
}

\author{
P. C. SHUKLA ${ }^{2}$ and R. D. SHARMA \\ Department of Veterinary Medicine, Haryana Agricultural \\ University, Hisar 125 004, India \\ Received Fanuary 30, 1989
}

\begin{abstract}
Shukla P. C., R. D. Sharma: Immunization of Bovine Calves With Cell Culture Vaccine Against Theileria annulata. Acta vet. Brno, 60, 1991: 79-86.

Theileria annulata (Hisar) was propagated in vitro up to passage 139. These cultures have been tested for immunogenicity by inoculating forty five c ossbred male bovine calves at passage 10,50 and 100 levels in varying cell concentrations i.e., $10^{4}$ cells $/ \mathrm{ml}, 10^{6}$ cells $/ \mathrm{ml}$ and $10^{8}$ cells $/ \mathrm{ml}$. Supernatant was $: 1$ o tested at passage 10 level.

All these calves were challenged by releasing infective Hyalomma anatolicum anatolicum nymphs, adults and ground up tick supernatant (GUTS) at passage levels 10,50 , anc 100 , respec iv $1 \mathrm{y}$, after one month of inoculat on.

The post-inoculation and post-challenge clinical reactions in the form of hyperthermia, lymphadenopathy and other clinical signs were recorded daily, parasitological reactions (i.e. appearance of macroschizonts in biopsy smears and piroplasmas in the blood smears) were recorded there times a week, and haematological changes (i. e. haemoglobin concentration, packed cell volume and total erythrocyte count) were followed twice a week. These observations were carried out for a period of one month of challenge.
\end{abstract}

Hyalomma anatolicum anatolicum, challenge, clinical signs, haematology, parasitology

In the face of non-availability of an effective chemotherapeutic agent, the development of a sui-table vaccine seemed to be of paramount importance for the control of bovine tropical theileriasis. Therefore, cell culture vaccine has been tried in various countries with varying degree of success (Pipano et al. 1977; Stepanova et al. 1982). The vaccine developed at one place may not be applicable as such at other places, probably because of the strain variation in Theileria annulata (Pipano and Shkap 1979; Ozkoc and Pipano 1981).

Therefore, in the present study lymphoblastoid cell cultures infected with Theileria annulata (Hisar) were cultured in vitro, so as to ascertain the passage level and dose of inoculum which may be immunogenic.

\section{Materials and Methods}

\section{Maintenance of ticks}

The clean nymphs were released on the ears of infected calves (having 2-8\% parasitaemia), and ears were examined daily. The fully engorged nymphs which dropped in the cloth bags were collected and kept in the B.O.D. incubator for moulting in to adults. These were used for experimental production of disease in susceptible bovine calves.

1 Part of $\mathrm{PhD}$. thesis submitted by the senior author to Haryana Agricultural University, Hisar.

2 Present address: Veterinary Medicine College of Vet. Science and A. H., Mhow (MP) 453446. (M.P.) India 


\section{Experimental production of disease in bovine calves}

These calves were infected with $T$. annulata by releasing 30 infected H.a. anatolicum adult ticks on the ears. The clinical observations as hyperthermia, lymphadenopathy, clinical signs and status of anaemia etc. were recorded daily. In addition, the lymph node biopsy smears and blood : smears were also examined daily for the stage of development of disease.

\section{Collection of material}

The isolation of $T$. annulata was made in vitro from the material collected from lymph node biopsies as per the technique by Brown (1979) and from buffy coat separated on lymphoprep ( $(B C P L)$ from the experimentally infected calves at an acute stage of the disease with $80 \%$ parasitaemia. Media used for in vitro isolation was RPMI - 1640 supplemented with $20 \%$ foetal bovine serum (Gibco).

\section{Inoculum}

The cultures were bulked to exactly $500 \mathrm{ml}$ at each passage levels. The doses were made by dilution or concentration of the culture to $1 \mathrm{ml}$ for $10^{4}$ and $10^{6}$ cells and $2 \mathrm{ml}$ for $10^{8}$ cells concentration for inoculation to the susceptible calves.

\section{Immunization studies}

A total of 45 crossbred male bovine calves (3-5 months of age) were inoculated subcutaneously . on the left side of the neck at each passage levels i. e. 10,50 and 100 in various cells concentrations in groups of five calves at each dose levels. Besides these, supernatant of the culture at passage 10 was also inoculated in a group of five calves separately.

After one month of inoculation all survival calves (i.e., 12,6 and 11 calves) at passage 10,50 and 100 levels respectively including control calves were challenged with 30 infective nymphs, adults or ground up tick supernatant (GUTS) prepared from 30 infected ticks at passage 10, 50 and 100 respectively.

The post-inoculation and post-challenge observations were carried out as follows.

\section{A. Clinical reactions. Hyperthermia.}

Temperature above $38.5^{\circ} \mathrm{C}$ was considered hyperthermia in this study. The duration and maximum temperature was also recorded daily.

Lymphadenopathy. Enlargement of prescapular parotid lymph node was recorded daily, by palpating the lymph nodes. The size of the lymph node at preinoculation, post inoculation and challenge were compared and graded as no enlargement $(-)$, slight $(+)$, Moderate $(++)$ and severe $(+++)$ enlargement.

Other clinical signs of the disease have also been recorded daily.

\section{B. Parasitological reactions}

The observations were recorded twice a week and they included:

Examination of lymph node biopsy smears

The smears were made from the fluid collected from enlarged lymph nodes and examined -(after staining with Giemsa's stain) for the presence of hyperplastic cells i. e., slight $\left(\mathrm{H}^{+}\right)$, moderate $(\mathrm{H}++)$ and severe hyperplasia $(\mathrm{H}+++)$. The appearance of macroschizonts $(\mathrm{Ma})$ was also recorded in these smears and graded as negative $\left(\mathrm{Ma}^{-}\right)$, few $\left(\mathrm{Ma}^{+}\right)$moderate $(\mathrm{Ma}++)$ and many ( $(\mathrm{Ma+++})$ macroschizonts per field.

Examination of Blood smears The Giemsa-stained peripheral blood smears were examined for the presence of piroplasms. The percent parasitaemia was determined by counting the number of parasitized erythrocytes per 500 cells in randomly selected microscopic fields.

\section{Haematological studies}

The blood was collected two times a week for the estimation of haemoglobin $(\mathrm{Hb})$, packed cell volume (PCV), total erythrocyte counts (TEC) and total leucocyte counts (TLC). 


\section{Results}

\section{A. At passage 10 level:}

\section{In $10^{4}$ cells group}

On inoculation one calf showed hyperthermia $\left(39.7^{\circ} \mathrm{C}\right)$ with varying degree of lymph node enlargement in all the calves. The macroschizonts were seen in only one calf with $1 \%$ piroplasms. One calf died due to nonspecific cause.

On challenge, lymphadenopathy was observed in all calves with appearance of macruschizonts in 3 calves and piroplasmas $(1 \%)$ in one calf. One calf died of theileriasis, while other calf due to other causes.

In $10^{6}$ cells group:

Thermal reaction $\left(39.7\right.$ to $40.3^{\circ} \mathrm{C}$ ) was seen in 4 calves but piroplasmas $(1 \%)$ were observed only in one calf, on inoculation.

On challenge two calves showed rise in temperature, but lymphadenopathy and parasitic reactions were observed in all the calves with death of one calf due to theileriosis.

In $10^{8}$ cells group:

The inoculated calves showed clinical reactions, with appearance of macroschizonts. The piroplasmas ( $1 \%$ ) were seen only in one calf with death of the calf due to disease, while one calf died of nonspecific causes.

On challenge, all the calves showed only clinical reactions and survived.

In the control group, all the eight calves suffered from theileriosis and five of them died, while 3 calves survived (Table 1).

Table 1

Numbers of calves showing clinical and parasitological reactions on inoculation with cell cultures of $T$. annulata schizonts at passage 10 and after challenge with infected nymphs

\begin{tabular}{|c|c|c|c|c|c|c|}
\hline $\begin{array}{c}\text { Dose of } \\
\text { inoculum }\end{array}$ & Status & Thermal reaction & $\begin{array}{l}\text { Lymphadeno- } \\
\text { pathy }\end{array}$ & Macroschizonts & Piroplasmas & Survival \\
\hline $1 \times 10^{4}$ cells & $\begin{array}{l}\text { PI } \\
\text { PC }\end{array}$ & $\left(1003.4^{\circ} \mathrm{F}\right)$ & $\left(++\right.$ to $\left._{4}^{5}+++\right)$ & $(+)_{3}^{1}$ & (1 1 \%) & $\begin{array}{l}4 \\
1\end{array}$ \\
\hline $1 \times 10^{6}$ cells & $\begin{array}{l}\text { PI } \\
\text { PC }\end{array}$ & $\left(103.4\right.$ to $\left.2104.6^{\circ} \mathrm{F}\right)$ & $(+$ to ++$)$ & $(+)_{5}$ & $\begin{array}{c}1 \\
(1 \%) \\
5\end{array}$ & $\begin{array}{l}5 \\
4\end{array}$ \\
\hline $1 \times 10^{8}$ cells & PI & $\begin{array}{c}\left(103.8 \text { to } 104.6^{\circ} \mathrm{F}\right) \\
5 \\
\left(103.2 \text { to } 106^{\circ} \mathrm{F}\right)\end{array}$ & $\begin{array}{c}(+ \text { to }++) \\
5\end{array}$ & $(+)_{5}$ & (rare to $1 \%$ ) & 3 \\
\hline Controls & $\begin{array}{l}\text { PC } \\
\text { PC }\end{array}$ & $\begin{array}{c}3 \\
\left(103.8 \text { to } 104{ }^{\circ} \mathrm{F}\right) \\
8 \\
\left(103.4 \text { to } 108.5^{\circ} \mathrm{F}\right)\end{array}$ & $\mid \begin{array}{c}(++ \text { to }+++) \\
3 \\
(+ \text { to }++) \\
8 \\
(++ \text { to }+++)\end{array}$ & $\begin{array}{c}(t) \\
(+ \text { to }++)\end{array}$ & (rare to $55 \%$ ) & $\begin{array}{l}3 \\
3\end{array}$ \\
\hline
\end{tabular}

PI = Post inoculation, $\mathbf{P C}=$ Post challenge

Figures in brackets indicate the range of maximum reactions in these animals

B. At passage 50 levels:

i) In $10^{4}$ cells group: In all the inoculated calves thermal reactions with lymphadenopathy was observed. Macroschizonts were seen in 3 calves but piroplasms (rare) were observed only in one calf. Two calves died of non-specific disease and three of them died of theileriosis during post-inoculation stage. 
ii) In $10^{6}$ cells group : All the calves showed thermal reaction $\left(102.6\right.$ to $\left.106^{\circ} \mathrm{F}\right)$ with moderate lymphadenopathy $(++)$. Three calves showed only macroschizonts but no piroplasmas were recorded in any calf. Three calves died due to nonspecific causes while two calves survived.

On challenge one calf exhibited thermal reaction $\left(103.6^{\circ} \mathrm{F}\right)$ with moderate lymphadenopathy and mild parasitological reactions. One calf died of non-specific disease and one calf survived.

ii) in $10^{8}$ cells group:

Clinical reactions were observed in all the calves with appearance of piroplasmas (up to $1 \%$ ) in 3 calves. One of the calf died of non-specific cause while 4 calves survived.

On challenge all clinical and parasitological reactions were observed (but are more severe) in all the calves. The piroplasmas (up to $2 \%$ ) were seen in two calves. Death of one calf resulted due to other causes while two calves died of theileriosis and one calf survived.

In the control groups, all the five calves had clinical theileriosis and died (Table 2).

Table 2

Numbers of calves showing clinical and parasitological reactions on inoculatoin with cell cultures of $T$. annulata schizonts at passage 50 and after challenge with infected ticks

\begin{tabular}{|c|c|c|c|c|c|c|}
\hline $\begin{array}{c}\text { Dose of } \\
\text { inoculum }\end{array}$ & Status & & $\begin{array}{c}\text { Lymphadeno- } \\
\text { pathy }\end{array}$ & Macroschizonts & Piroplasms & Survival \\
\hline $1 \times 10^{4}$ cells & & (103 to $\left.{ }^{5} 106^{\circ} \mathrm{F}\right)$ & $\left(+\right.$ to $\left.^{5}++\right)$ & $\stackrel{3}{(+)}$ & $\begin{array}{c}1 \\
\text { (Rare) }\end{array}$ & - \\
\hline $1 \times 10^{\circ}$ cells & $\begin{array}{l}\text { PC } \\
\text { PI }\end{array}$ & $\begin{array}{c}\overline{5} \\
\left(102.6 \text { to } 106^{\circ} \mathrm{F}\right)\end{array}$ & $\begin{array}{c}\overline{4} \\
(t \text { to }++)\end{array}$ & $\begin{array}{l}\overline{3} \\
(+)\end{array}$ & & \\
\hline $1 \times 10^{8}$ cells & $\begin{array}{l}\text { PC } \\
\text { PI }\end{array}$ & $\begin{array}{c}\left(103.6^{\circ} \mathrm{F}\right) \\
5\end{array}$ & $(+$ to $4++)$ & $\begin{array}{l}1 \\
4\end{array}$ & $\begin{array}{c}1 \\
\text { (Rare) } \\
3\end{array}$ & $\begin{array}{l}1 \\
4\end{array}$ \\
\hline Controls & $\begin{array}{l}\text { PC } \\
\text { PC }\end{array}$ & $\begin{array}{c}\left(103.4 \text { to } 105.2^{\circ} \mathrm{F}\right) \\
\left(103.4 \text { to } 105^{\circ} \mathrm{F}\right) \\
5^{\circ} \\
\left(106 \text { to } 108^{\circ} \mathrm{F}\right)\end{array}$ & $\left(\begin{array}{c}(++ \text { to }+++) \\
4 \\
(+ \text { to }++) \\
5 \\
(+++)\end{array}\right.$ & $\begin{array}{c}(+) \\
4 \\
(+) \\
5 \\
(++)\end{array}$ & $\begin{array}{c}\text { (Rate to } 1 \% \text { ) } \\
2 \\
\text { (1 to } 2 \% \text { ) } \\
2 \\
\text { (Rare to } 3 \% \text { ) }\end{array}$ & $\begin{array}{l}1 \\
0\end{array}$ \\
\hline
\end{tabular}

PI $=$ Post inoculation. $\mathbf{P C}=$ Post challenge

Figures in brackets indicate the range of maximum reactions in these animals.

\section{At passage 100 levels:}

i) In $10^{4}$ cells group: All inoculated calves exhibited clinical reactions while macroschizonts were seen in two calves. One calf died due to non-specific causes. whole four calves survived.

On challenge, severe clinical and parasitological reactions were observed with appearance of piroplasmas up to $40 \%$. Three calves died of theileriosis and one calf survived.

ii) In $10^{6}$ cells group: Clinical reactions were seen in most of the calves with appearance of macroschizonts in three calves. Two calves died due to other causes while 3 calves survived.

On challenge, only mild thermal reaction with lymph node enlargement was. seen, but no parasitological reactions were observed in any of the calves and. all the calves withstood the challenge and survived. 
iii) In $10^{8}$ cells group: Severe thermal reactions $\left(103.8-105^{\circ} \mathrm{F}\right)$ with lymphadenopathy and parasitological reactions were recorded. Death of one calf due to other causes resulted and four calves survived.

On challenge, only mild clinical reactions were seen without any parasitological reactions in any calves and all the calves withstood severe GUTS challenge and survived (Table 3).

Table 3

Numbers of calves showing clinical and parasitological reactions on inoculation with cell cultures of $T$. annulata schizonts at passage 100 and after challenge with GUTS

\begin{tabular}{|c|c|c|c|c|c|c|}
\hline $\begin{array}{c}\text { Dose of } \\
\text { inoculum }\end{array}$ & Status & Thermal reaction & $\begin{array}{c}\text { Lymphadeno- } \\
\text { pathy }\end{array}$ & Macroschizonts & Piroplasmas & Survival \\
\hline $1 \times 10^{2}$ cells & PI & ${ }^{5}$ & 5 & $(+)$ & - & 4 \\
\hline & PC & $\left(103.0\right.$ to $\left.103.4^{\circ} \mathrm{F}\right)$ & 4 & 4 & $\stackrel{3}{(2)}$ & 1 \\
\hline $1 \times 10^{2}$ cells & PI & $\left(103.2\right.$ to $\left.104.4^{\circ} \mathrm{F}\right)$ & $\begin{array}{l}5 \\
(+)\end{array}$ & $(+)$ & (2) & 3 \\
\hline & PC & $\left(103^{\circ} F\right)$ & $\begin{array}{l}3 \\
(+)\end{array}$ & - & - & 3 \\
\hline $1 \times 10^{2}$ cells & PI & $\left(103.8\right.$ to $\left.105^{\circ} \mathrm{F}\right)$ & $(+$ to ++$)$ & $\stackrel{3}{(+)}$ & $\stackrel{3}{3}$ & 4 \\
\hline Control & $\begin{array}{l}\text { PC } \\
\text { PC }\end{array}$ & $\begin{array}{c}\left(102.8^{\circ} \mathrm{F}\right) \\
\quad{ }^{5} \\
\left(105.2 \text { to } 106{ }^{\circ} \mathrm{F}\right)\end{array}$ & $\begin{array}{l}\left(+\begin{array}{l}4 \\
5\end{array}\right) \\
(+++)\end{array}$ & $\left(+\right.$ to $\left.^{5}+++\right)$ & $\begin{array}{c}- \\
5 \\
(5 \text { to } 60 \%)\end{array}$ & $\begin{array}{l}4 \\
1\end{array}$ \\
\hline
\end{tabular}

PI = Post inoculation. $\mathbf{P C}=$ Post challenge

Figures in brackets indicate the range of maximum reactions in these calves

Haematological values indicated mild anaemic status on inoculation of the cell cultures at fassage 10 and 50 while at 100 , on inoculation, all the haematological values remained almost unaltered.

However, on challenge, marked anaemia was observed at passage 10 and 50 levels while a mild decrease in erythrocytic indices was observed with a little increase in total leucocytic count at passage 100 levels.

Amongst the varying cells concentrations, in $10^{6}$ cells group at all passage levels the percent decrease in erythrocytic indices was recorded to be minimum on inoculation as well as on challenge (Table 4).

Table 4

Immunization of bovine calves culture vaccine at different passages at $10^{\circ}$ cell concentration; Effect on erythrocytic indices (in percent) post inoculation and post challenge

\begin{tabular}{|c|c|c|c|c|c|c|}
\hline \multirow{3}{*}{ Erythrocytic indices } & \multicolumn{6}{|c|}{ Passage levels } \\
\hline & \multicolumn{2}{|c|}{$\mathbf{P}_{10}$} & \multicolumn{2}{|c|}{$P_{50}$} & \multicolumn{2}{|c|}{$\mathbf{P}_{100}$} \\
\hline & $\begin{array}{c}\text { post } \\
\text { inoculation }\end{array}$ & $\begin{array}{c}\text { post } \\
\text { challenge }\end{array}$ & $\begin{array}{c}\text { post } \\
\text { inoculation }\end{array}$ & $\begin{array}{c}\text { post } \\
\text { challenge }\end{array}$ & inoculation & $\begin{array}{c}\text { post } \\
\text { challenge }\end{array}$ \\
\hline $\begin{array}{l}\text { Haemoglobin (gm \%) } \\
\text { PCVA (\%) } \\
\text { TEC (Millions/cm) }\end{array}$ & $\begin{array}{l}10.99 \\
15.09 \\
33.53\end{array}$ & $\begin{array}{l}16.66 \\
29.91 \\
48.07\end{array}$ & $\begin{array}{r}9.64 \\
20.19 \\
19.16\end{array}$ & $\begin{array}{l}16.01 \\
25.93 \\
25.47\end{array}$ & $\begin{array}{r}7.60 \\
1.65 \\
17.09\end{array}$ & $\begin{array}{l}19.10 \\
16.98 \\
18.60\end{array}$ \\
\hline
\end{tabular}

* Reduction in erythrocytic indices from the normal. 


\section{Discussion}

The supernatant of the culture at passage 10 was found to be pathogenic (Shukla and Sharma, 1988). Similar results have been observed by Tsur and Pipano (1966) by using supernatant of monolayer cultures.

A. At Passage 10:

In the inoculated calves, appearance of piroplasms (up to $1 \%$ ) with anaemia in all cell concentrations indicated that the inoculum was pathogenic and needed further passaging. But, on challenge, development of clinical and parasitological reactions with marked anaemia and death of one calf at $10^{4}$ and $10^{6}$ cells groups showed that inoculum was not protective.

Similar findings have been noted by Pipano and Israel (1971) on inoculation of cell cultures between 10-35th passages and by Gill et al. (1978) at Passage-15.

\section{B. At Passage 50:}

The development of clinical, parasitological reactions with reduction in erythrocytic indices in the inoculated calves at all cells groups but death of three calf at $10^{4}$ cell group due to theileriosis revealed that inoculum was still pathogenic.

On challenge, the calves exhibited clinical reactions of varying degree with appearance of piroplasms (in $10^{6}$ and $10^{8}$ cells groups) and death of two calves (in $10^{8}$ cells group) due to theileriosis, suggest that culture at this passage level was not immunogenic.

On the contrary, Pipano and Israel (1971) did not observe any reaction in the calves on inoculation/challenge in calves inoculated at 50th-120th passage.

So, the results obtained at passage- 50 on inoculation challenge were almost similar to that of Passage-10. These results were in accordance with the observations of Tsur et al (1964), Zablotskii (1967) and Hashemi-Fesharki and Shad-Del (1973).

\section{At Passage 100:}

The inoculated calves exhibited clinical and only mild parasitological reactions but rare piroplasms in $10^{8}$ cells group without any appreciable haematological changes were observed. These findings indicated that the inoculum was not completely attenuated.

On challenge, clinical reactions with appearance of piroplasms (up to $40 \%$ ) and mortality of three calves (in $10^{4}$ cells groups) suggested that this cells concentration was not sufficiently protective. However, the calves of $10^{6}$ and $10^{8}$ cells groups, showed no any sort of reactions and withstood severe GUTS challenge except mild hyperthermia in one calf in each of $10^{6}$ and $10^{8}$ cells groups. These observations revealed that this culture was appreciably immunogenic and high level of passaging leads to attenuation of the cultures. Similar results have been reported by Tsur et al. (1964) Pipano and Israel (1971), Pipano (1974, 1976), and Stepanova et al. (1982).

Amongst the varying cells concentrations, at $10^{6}$ cells concentrations, only mild clinical and partial parasitological reactions without any mortality at each passage levels at any stage was observed. These results suggested that $10^{6}$ cells 
concentration should be preferred. Similar recommendations have been reported by Pipano (1976), Gill et al. (1980) and Subramanian et al. (1980).

Haematological observations indicated no appreciable changes in the erythrocytic indices at P 100 at any stage but marked anaemia was evident in the calves at $P 10$ and $P 50$ levels on challenge.

Sina and Gunary (1982) also observed the similar results on inoculation with cell cultures in the calves.

The calves inoculated with cell cultures of Passage- 100 in $10^{6}$ cells concentration did not show any sort of reactions, except a mild reduction in erythrocytic indices. But on challenge, a slight reaction to severe GUTS challenge was observed and all the calves survived.

Hence, from these results it may be concluded that this inoculum has been proved to be a promising, safe and potent vaccine (Pipano 1981).

\section{Imunizace telat proti Theileria annulata vakcínou $\mathrm{z}$ buněčné kultury}

Imunogenita kultur Theileria annulata (Hisar) pomnožené in vitro do pasáže 139, byla testována inokulací 45 telatům - křížencům samčího pohlaví v desáté, padesáté a sté pasáži. Bylo použito koncentrací $10^{4}, 10^{6}$ a $10^{8}$ buněk $/ \mathrm{ml}$. Supernatant byl testován při desáté pasáži.

Všechna telata byla čelenžována vystavením infekčním nymfám, dospělým jedincům a supernatantu $\mathrm{z}$ mletých těl klištat Hyalomma anatolicum anatolicum na úrovních f asćźí 10, 50 a 100.

Reakce po inokulaci a čelenži zahrnovala zvýšenou teplotu, lymfadenopatii i další klinické př́iznaky, dále nálezy makroschizontů, $v$ nátěrech $\mathrm{z}$ biopsií a piroplasmy $\mathrm{v}$ krevních nátěrech. Po dobu 1 měsíce po čelenži byla sledována koncentrace hemoglobinu, hematokritová hodnota a počty erytrocytů.

\section{Иммунизация телят от Theileria annulata вакциной из клеточной культуры}

Иммуногенез культур Theileria annulata (Hisar), размноженные ин витро в пассаж $P$ 139, проверяли инокуляцией 45 телятам - помеси самцев на десятом, пятидесятом и сотом пассаже. Применяли концентрации $10^{4}, 10^{6}$ и $10^{8}$ клеток/мл. Супернатант проверяли на десятом пассаже.

Все телята были челенжированы инфицированным нимфам, взрослым особям и супернатанту из молотых клещей Hyalomma anatolicum anatolicum на уровне пассажей 10,50 и 100.

Реакция после инокуляции и челенжирования включала повышенную температуру, лимфаденопатию и другие клинические признаки, а также были выявлены макрошизонты в мазках из биопсий и в мазках крови - пироплазмы. В течение одного месяца челенжирования исследовали концентрации гемоглобина, величину гематокритов и численность эритроцитов.

\section{Acknowledgements}

The senior author is thankful to Indian Council of Agricultural Research, New Delhi for awarding the Senior Research Fellowship for conducting the present work. 


\section{References}

BROWN, C. G. D.: Propagation of Theileria. In: K. Maramorosch and H. Hirumi. Editors; Practical tissue culture applications. Academic Press, New York, pp. 2230 (1979).

GILL, B. S.-BHATTACHARYULU, Y.-KAUR, D. - SINGH, A.: Vaccination against bovine tropical theileriasis (Theileria annulata) Nature, 264: 1976: $355-356$

GILL, B. S.-BANSAL, G. C.-BHATTACHARYULU, Y.-KAUR, D.-SINGH, A.: Immunological relationship between strains of Theileria annulata, Deschunkowskay and Luhs, 1904. Res. Vet. Sci., 29 (1) 1980: 93-97

HASHEMI-FESHARKI, R.-SHAD-DEL, F.: Vaccination of calves and milking cows with different strains of Theileria annulata. Amer. J. Vet. Res., 34 (11): 1973: 1 465-1 467

OZKOC, U.-PIPANO, E.: Trials with cell culture vaccine against theileriosis in turkey. Proc. of Int. Nat. Conference on Advances in the Control of Theileriosis. Nairobi, 9-13 Feb. (1981)

PIPANO, E.: Immunological aspects of Theileria annulata infection. Bull. Off. Int. Epiz., 81, 1974: $139-159$

PIPANO, E.: Basic principles of Theileria annulata control - Report In: J. B. Henson and Campbell M. Editors: International Workshop on Theileriosis Nairobi, 7-9th Oct. (1976)

PIPANO, E.: Schizonts and tick stages in immunization against Theileria annulata infection. Proc. of Int. Nat. Conf. on Advances in the control of Theileriosis, Nairobi, 9-13th Feb. (1981).

PIPANO, E.-ISRAEL, V.: Absence of erythrocyte forms of Theileria annulata in calves inoculated with schizonts from a virulent field strain grown in tissue culture. J. Protozool, 18: Suppl. 137: 1971 - 37.

PIPANO, E.-GOLDMAN, M.-SAMISH, M.-FRIEDHOFF, K. T.: Immunization of cattle against Theileria annulata using killed schizont vaccine. Vet. Parasitol., 3, 1977: 11-22

PIPANO, E.-SHKAP, V.: Attenuation of two turkish strains of Theileria annulata. J. Protozool, 26, 1979: 80A.

SHUKLA, P. C. - SHARMA, R. D.: Immunization trials in bovine calves inoculated with supernatant of in vitro cell cultures infected with Theileria annulata. Indian J. Vet. Med., 8, 1988: $58-60$

SINA, M.-GUNARY, M.: Erythrocytes, leucocytes, haemoglobin, packed cell volume, total bilirubin and copper in the blood of splenectomized and intact calves inoculated with attenuated or virulent Theileria annulata schizonts. Pendik Veteriner Mikrobiyologi Enstitusu Bergisi, 13, 1981; 35-39

STEPANOVA, N. I.-ZABLOTSKII, V. T.-RASULOV, K. I.: Vaccine prophylaxis of bovine theileriosis. Trudy Vessoyuznogo Instituta Epsperimental noi Veterinari 56, 1982: Abstr. Vet. Bull. 53, 1983: 7794

SUBRAMANIAN, G.-VERMA, J. C.-NAITHANI, R. C.: Isolation, cultivation and preservation of schizonts of Theileria annulata Proc. of Seminar on Haemoprotozoan diseases (C. W. Asian/Australian region) of Domestic animals. Haryana Agricultural University, Hisar, 27th Oct. -1 st Nov. (1980).

TSUR, I.-PIPANO, E.: Attenuation of virulence of strains of Theileria annulata by growth and passage through tissue culture. J. Pro 'ozool, 13, Suppl. 140, 1966: 33-34

TSUR, I.-ADLER, S. - PIPANO, E.-SENFT, Z.: Proc. of First Int. Nat Congress of Parasitology; Rome, 1, 1964: 266 (Cited by Pipano, 1981).

ZABLOCSKII, V. T.: Use of tissue culture in the study of Theileria annulata. Veterinariya, Moscow No. 9: 1967: 66-69. Abstr. Vet. Bull., 38, 1968: 2652 